\title{
Tutkijalta työyhteisöille
}

Aini-Kristiina Jäppinen (2012) Onnistu yhdessä! Työyhteisön kehittämisen 10 avainta. PS-kustannus.
AINI-KRISTIINA Jäppisen kirja Onnistu yhdessä! Työyhteisön kehittämisen 10 avainta esittelee kirjoittajan omaa kehittämismenetelmää. Tekijä suosittelee kirjaa työtiimeille ja harrastusryhmille, niin esimiehille kuin keille tahansa erilaisten yhteisöjen jäsenillekin. Soveltuupa teos hänen mukaansa lisäksi koulutuspäiville ja laadun arviointiin, kuten myös tueksi organisaation muutoksiin ja kriisitilanteisiin. Lupaukset ovat suuret ja moninaiset. Kun lupaa kaikille kaiken, riskiksi muodostuu se, ettei lopulta kukaan saa erityisesti mitään. Tämän riskin realisoitumista voi kukin lukija arvioida omasta näkökulmastaan.

Kirja sisältää likimain kaikki työyhteisöjen kehittämisen näkökulmasta keskeiset teemat. Siinä käsitellään esimerkiksi jaettua johtajuutta, yhteisöllisyyttä, moniäänisyyttä, vuorovaikutusta, asenteita ja ajattelutapoja, toimintaa, luottamusta, oman toiminnan arviointia, asiantuntijuutta, joustavuutta, sitoutumista, vastuunottoa, neuvottelua, päätöksentekoa ja kontrollia. Kirjan luvut ovat lyhyitä: lukujen otsikot sisältävää sisällysluetteloa riittää neljä sivua, kun koko kirjan mitta on vain 144 sivua. Kovin syvälle ei mihinkään teemaan mennä.

Jäppinen toteaa kirjansa esipu- heessa pyrkineensä kirjoittamaan niin, että asiat ja käsitteet on avattu ja selitetty selkeästi, jopa hauskasti. Tämän lupauksensa Jäppinen lunastaa, sillä kirja on helppolukuinen. Se on osoitus tutkijan monitaitoisuudesta, kyvystä kirjoittaa tarvittaessa myös muunlaisella kuin tutkimuksen formaatilla. Yleisesti ottaen tutkijoiden kirjoittamissa yleistajuisissa kirjoissa minua vaivaa se, että jättäessään tutkimuksellisen viittauskäytännön pois tutkija tulee vaivihkaa siirtäneeksi muiden oivallukset omikseen. Jäppinen liikkuu kuitenkin niin yleisellä tasolla, että olettaisin hänen onnistuneen välttämään tämän ansan.

Kenties tämän yleisellä tasolla liikkumisen vuoksi Onnistu yhdessä! on kirja, jonka sisällölle on helppo nyökytellä. Noinhan ne asiat epäilemättä ovat. Kirjan rakenne on selkeä ja toimiva. Kirjalle annetaan jopa käyttöohjeet. Lukuihin on myös upotettu runsaasti reflektointia ja keskusteluja synnyttäviä kysymyksiä. Löytyypä kirjan lopusta tilaa omille muistiinpanoillekin. Kun kirja vielä on ulkoasultaan iloinen, siihen on helppo tarttua.

Valitettavasti kirja toistaa myös likipitäen kaikki latteudet, joita konsultit tyypillisesti käyttävät. Niin ikään kirja on tulvillaan erilaisia kielikuvia ja vertauksia, jotka johtavat lukijaa milloin mihinkin suuntaan hämärtäen varsinaisen asian. On ovia, avaimia, kuorolaulua, talonrakennusta, trampoliinia, matkaa, tilkkutäkkiä ja urheilua. Tämä sekamelska vie valitettavalla tavalla voimaa kirjoittajan omaperäisiltä kehitelmiltä ja oivalluksilta, joiden varaan kirjoittaja ei ole uskaltanut heittäytyä. Olisi ollut toivottavaa, että Jäppinen olisi valinnut jonkin vertauskuvien maailman ja pitäytynyt siinä.

Näinä päivinä tutkijoita kannustetaan kepillä ja porkkanalla keskittymään kansainvälisen tutkijayhteisön sisäiseen keskusteluun. Suomenkielinen julkaiseminen on tehty toisarvoiseksi ja erityisen kannattamattomaksi on tullut kirjoittaa yleistajuinen kirja. Mielestäni Jäppisen teoksen suurin arvo liittyykin tähän. Se ilmentää toisinajattelua, eräänlaista tutkijan vastarintaa. Teos kertoo siitä, että Jäppisellä on vilpitön halu antaa oma panoksensa suomalaisen työelämän kehittämiseen, vaikka tähän työhön käytetty aika on pois tutkijanuran meriittien kerryttämiseltä. Hatunnoston arvoinen teko ainakin minun mielestäni.

Anu Järvensivu

$F T$, sosiologian dosentti, Tampereen yliopisto erikoistutkija, Työterveyslaitos 